\title{
Ageing and the Economy: Time for a Debate Based on Evidence
}

\author{
James Doughney \\ Victoria University, Australia
}

\begin{abstract}
Policy discussions about ageing have too long taken for granted the untested proposition that population ageing will create an almost insurmountable economic burden for future generations. This paper first outlines the main claims of the 'ageing crisis' literature: ageing reduces labour force participation; increased dependency of non-workers upon workers will reduce future living standards; and future taxpayers will bear the cost of their parents' and grandparents' longevity. The paper then critically evaluates the evidence. Using an original model that combines economic and productivity growth with projected labour force participation rates, the paper concludes that the above claims are, at best, vastly exaggerated. Indeed, on reasonable assumptions, the model suggests that the 'crisis' claims are a furphy.
\end{abstract}

\section{Introduction}

The debate in Australia about ageing and the economy is the social scientific version of a nanoparticle based optothermal nanoconvertor. ${ }^{2}$ In physics and chemistry these are called nanorods. The past four Commonwealth budgets (2002-5) have put the ageing in prise de position and, last year, the Productivity Commission made it the subject of another magnum opus (PC 2005). Yet the debate itself has been minute - a nanodebate, perhaps. The dominant view is almost taken for granted. Phrases such as 'ageing crisis' are infrequently contested. Worse is that the policy vernacular absorbs them like punctuation. Indeed the debate in Australia about ageing and the economy is a nanorod because nanorods absorb light and raise temperatures: that is, they generate a lot of heat but do so at the expense of enlightenment!

Below are two exquisite examples of 'nanorodic' commentary on ageing and the economy. The first is

Copyright (C) 2006 Victoria University. This document has been published as part of the Journal of Business Systems, Governance and Ethics in both online and print formats. Educational and non-profit institutions are granted a nonexclusive licence to utilise this document in whole or in part for personal or classroom use without fee, provided that correct attribution and citation are made and this copyright statement is reproduced. Any other usage is prohibited without the express permission of the from a 2004 article on the Organisation of Economic Co-operation and Development web site, 'Ageing societies and the looming pension crisis' (OECD 2004):

If nothing is done quickly to
extend working lives, living
standards will fall in the course of
the coming decades. We know,
because of the ageing of our
populations, that there will be

1 Head Work and Economic Policy Research Unit Victoria University, Melbourne. First presented to the Group Training Association, Victoria State Conference, 13 July 2005. I thank participants for their questions and comments. Thanks also to two anonymous reviewers. The usual caveat applies.

2

Chou C-H, Chen C-D \& Wang CRC (2005). See also Ball (2005). 
fewer and fewer persons of working age to support more and more older people ... The first step governments can take is to eliminate provisions that subsidise early withdrawal from active life ... Without reform, and without a change in attitude, it will be our children and grandchildren who will pay the price.

The second truly beggars belief. It is from an article by Philip York in the May 2004 New Observer magazine titled 'The retirement crunch: Older, poorer and unsustainable':

Governments around the world are in crisis as pension and healthcare costs are increasing exponentially and, if governments are in crisis, citizens are in crisis. Tough decisions need to be made especially when it comes to healthcare, but at present few are prepared to make them because of the ethical and moral implications. Spiralling healthcare costs alone threaten to cripple the richest nations as doctors, patients, and their loved ones especially, seem to consider death almost optional as lives are extended (sometimes for only days) at enormous expense...' (York 2004, p. 33; emphasis added)

Of course, professionals and patients' families make difficult decisions daily in hospitals, and these decisions are related both to patients' needs and the resources available to prolong and save lives. However, once we start making those decisions according unsubstantiated and rhetorical claims of an 'ageing crisis', ageing people will be in serious trouble. Phrases like 'cripple', 'exponentially', 'governments are in crisis, citizens are in crisis', 'spiralling healthcare costs' and 'tough decisions need to be made' unfortunately make good sound grabs. Prime Minister John Howard's 2002 claim that Australia's suffers from a 'cult' of early retirement is another example. They become threads in the fabric of public discourse and, even if false, exert an almost subliminal influence.

In this paper I therefore hope to expose not only the more flamboyant claims about ageing and the economy but also the more reasoned of the dominant contributions. The best way to clarify the problem is to expose such contributions to evidence and reasonable argument. Below are the essential claims in the dominant literature, and I will deal with each in turn in the following sections:

1. Population ageing reduces labour force participation:

- Early retirement has cut labour force participation among older workers.

- Lower labour force participation will increase the dependency ratio significantly.

2. An increased dependency ratio will 'reduce' average living standards in the future:

- Average living standards will fall absolutely.

- Average living standards will fall relatively.

3. The cost of an ageing population will be born by taxpayers inter-generationally:

- Our children and grandchildren will experience higher taxes and or inferior government services.

The background arguments in this paper will help us to discuss more important problems, such as skills shortages and skills formation in Australia, with greater clarity. They will do so by explaining that population ageing is not such an economic problem after all. Attention should be diverted to skills, education and making older workers and retirees feel valued, in part for their skills. They, we, must not feel like a burden on society.

\section{Ageing, labour force participation and dependency ratios}

The claim that population ageing reduces labour force participation is almost a truism in current circumstances. The average or aggregate participation rate is defined as the percentage of the civilian population aged 15 and older that is either employed or seeking employment (i.e. in the labour force). As women have had fewer children and life expectancy has increased, the average age of the population 
has grown. This also means that there are proportionately more people in the older age groups (cohorts), including retiree cohorts. The average participation rate is bound to fall if such trends continue. Table 1 gives some of the relevant data and estimates.

Table 1 Australia's population, historical trends and predictions 1947-2051

\begin{tabular}{|c|c|c|c|c|c|}
\hline & 1947 & 1971 & 2005 & $2021(a)$ & $2051(a)$ \\
\hline Total population & $3,773,800$ & $7,579,400$ & $20,328,600$ & $19,662,800$ & $23,368,400$ \\
\hline Total fertility rate & 3.08 & 2.94 & 1.77 & 1.7 & 1.7 \\
\hline Life expectancy-female & 70.6 & 74.5 & 82.8 & 86.0 & 87.7 \\
\hline Life expectancy - male & 66.1 & 67.8 & 77.8 & 81.7 & 84.2 \\
\hline Median age & 30.7 & 27.5 & 36.6 & 40.7 & 45.2 \\
\hline $\begin{array}{l}\text { Not in labour force to labour } \\
\text { force ratio }\end{array}$ & 1.38 & 1.33 & 0.98 & 1.05 & 1.26 \\
\hline Average or aggregate labour & 1949-50avg. & August & August & $2024-25$ & $2044-45$ \\
\hline force participation rate & $58.0 \%(b)$ & $61.0 \%(b)$ & $64.8 \%$ & $59.9 \%$ (c) & $56.3 \%(\mathrm{c})$ \\
\hline Age cohort & \multicolumn{5}{|c|}{ Proportion of population in key age cohorts (\%) } \\
\hline $0-14$ & 25.1 & 28.7 & 19.6 & 16.9 & 15.1 \\
\hline $15-64$ & 66.8 & 63 & 67.3 & 64.3 & 59.1 \\
\hline $65-84$ & 7.7 & 7.8 & 11.6 & 16.3 & 20.0 \\
\hline 85 and older & 0.4 & 0.5 & 1.5 & 2.4 & 5.8 \\
\hline Total (rounded) & 100.0 & 100.0 & 100.0 & 100.0 & 100.0 \\
\hline
\end{tabular}

(a) Series B, mid-range projections (ABS 2005b, 32220 )

(b) Reserve Bank of Australia (RBA), Australian economic statistics, historical data, table 43 http://www rba gov au/Statistics/op8 index html\#section4

(c) Productivity Commission estimates (PC 2005, p 84 table 32 )

Sources (all other): ABS (2006, 1301 0; 2005a, 3101 0; 2004, 3105065 001; 2005b, 3222 0)

No one disputes that the population is ageing or, other things being equal, that the aggregate Australian participation rate will decline. Data such as those in table 1 are unambiguous. Chart 1 contains a view over time of the proportion of the population that is aged 65 and older. The dispute rather turns on the significance of these data and projections and on the various associated claims the data are used to support. One associated claim is that of the 'cult' of early retirement (Howard 2002). Let us deal with the question of early retirement first. Chart 2 refutes the claim, and chart 3 explains why. When we look at the relevant older-age cohorts we see that participation in the labour force has actually increased. The reason is that women's participation has grown dramatically in aggregate and in all cohorts.

Chart 1 Proportion of Australian population aged 65 and older persons 1950-2051

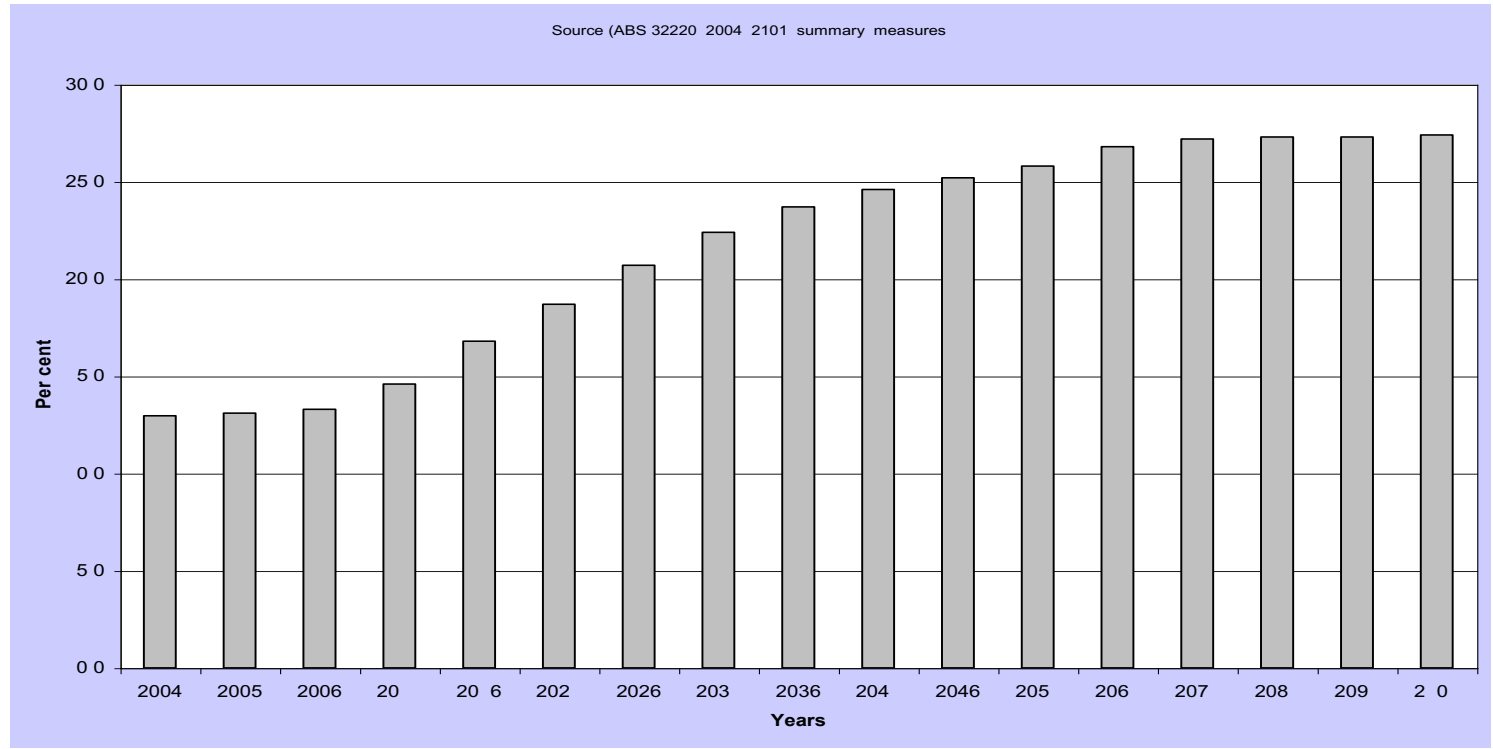

Sources: ABS $(2005,1301.0 ; 2004 a, 3101.0 ; 2004 b, 3105.0 .65 .001 ; 2003,3222.0)$ 
Both the increase in women's labour force participation and the gap remaining between men's and women's rates have potential regarding Australia's skill requirements. Yet women comprise about one in ten construction workers but almost eight in ten workers in health and community services and seven in ten in education. Women likewise make up fewer than one in four managers-administrators and one in ten workers in trades and related areas (Doughney et al. 2003).

Now when we examine the aggregate participation rate more closely it is easy to see that it is similar to another ratio called the dependency ratio. The dependency ratio can be measured a number of ways, but table 1 uses the ratio of the population not in the labour force (children and retirees) to the labour force. The idea is to grasp the extent to which the economically active population is supporting those who are not. While it is clear that the dependency ratio will rise for the same reasons that the participation rate will fall, it is important to put its rise into perspective. This will help us in turn to assess its significance.

Chart 2 Average or aggregate participation rates Australia persons 1978-2003

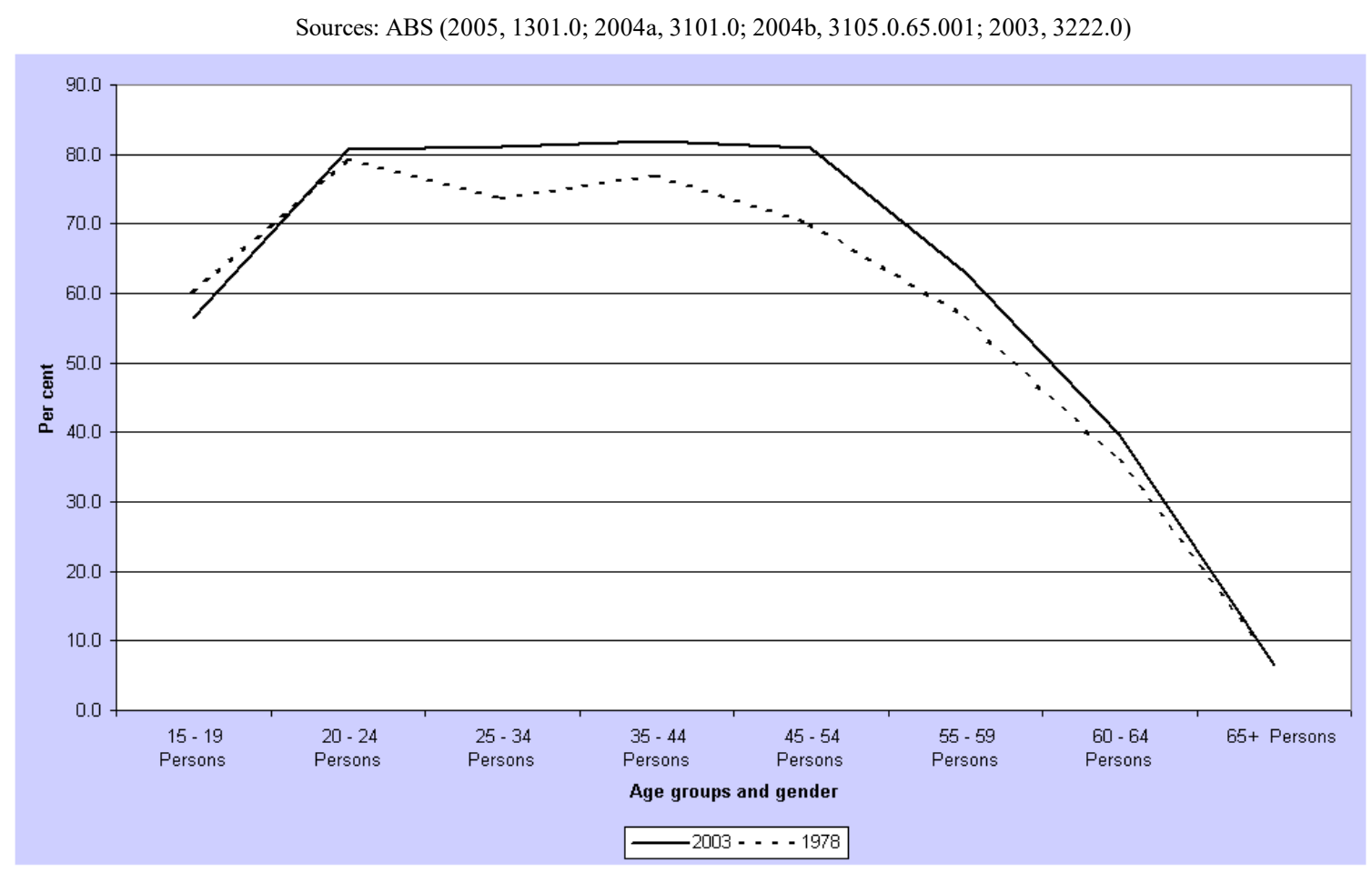

Table 1 demonstrates that those who see danger in a higher dependency ratio will have to argue a case. That is, by putting the ratio into perspective, it is possible and appropriate to ask 'what is so significant about an increase such as this?' The current dependency ratio is low by historical standards. A labour force member on average supports one person who is not in the labour force at present. In the immediate post world war 2 years the ratio was about one to 1.38 not in the labour force. It is projected to rise to about one to 1.25 by the middle of this century. In fact by the middle of this century it will be declining again, as chart 4 indicates. ${ }^{3}$

This section of the paper then has answered the first set of claims presented in the dominant ageing literature. It is easy enough to see from the data alone, with little additional argumentation, that:

While population ageing has and will reduce aggregate labour force participation rates:

a. Early retirement has not cut labour force participation among older workers. Rather older cohort participation rates have been increasing because of increased female participation. This trend should continue. 
b. Lower aggregate labour force participation rates and the dependency ratio are very similar ratios and change over time for much the same reasons. The data by themselves do not demonstrate that the dependency ratio's projected rise is significant.

\section{Chart 3 Average or aggregate participation rates Australia by gender 1978-2003}

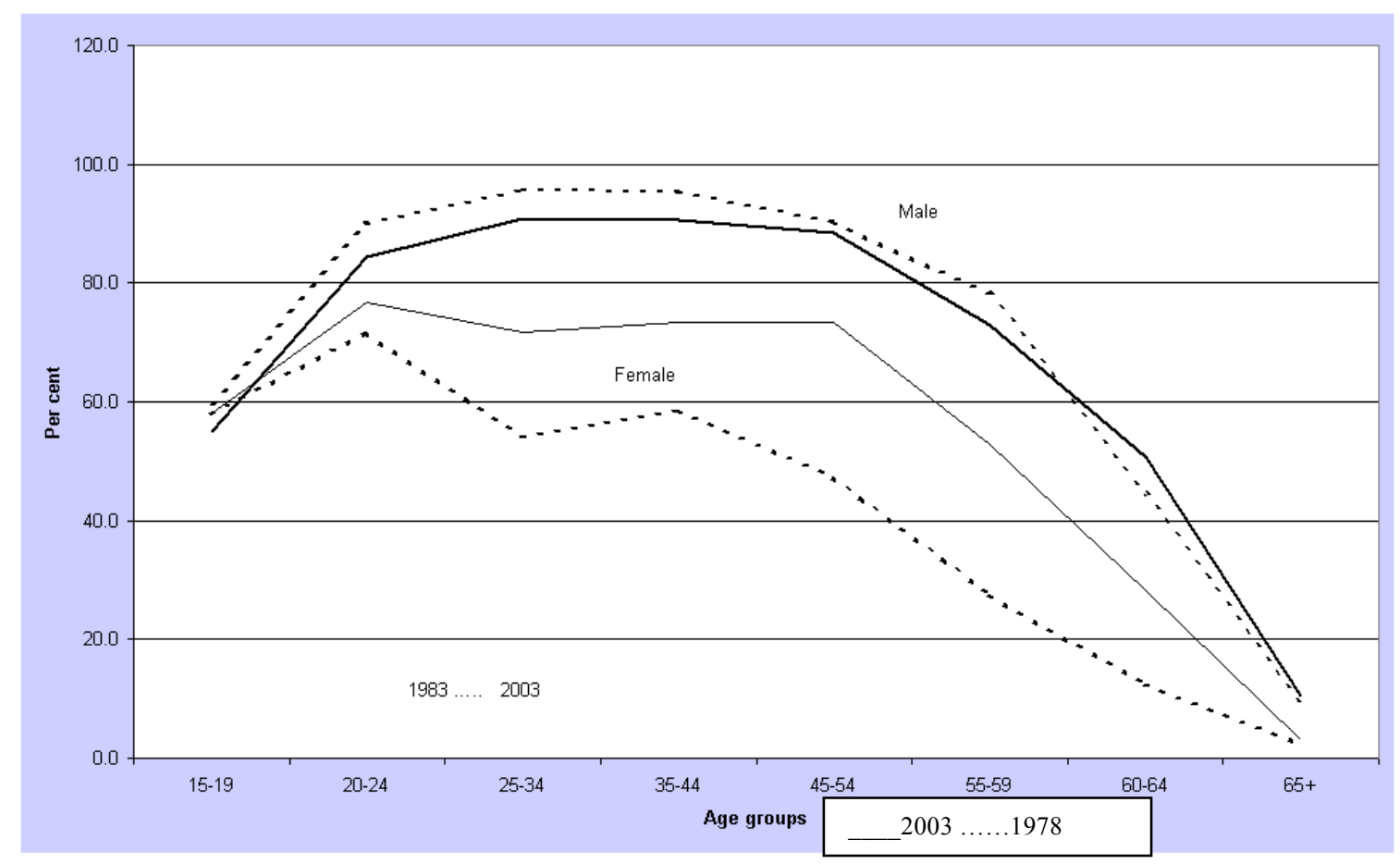

Sources: ABS $(2005,1301.0 ; 2004 a, 3101.0 ; 2004 b, 3105.0 .65 .001 ; 2003,3222.0)$

It is curious therefore that one of the more reasoned official contributions, that by the Productivity Commission (PC 2005), should focus in its overview on the aggregate participation rate. Its key point summary emphasises that 'overall participation rates are projected to drop from around 63.5 per cent in 2003-04 to 56.3 per cent by 2044-45' (PC 2005, p. xii). The summary does nothing to set these figures in perspective. Fortunately the body of the PC's report is subtler. However, the commission is well aware that its key point summaries go into its media releases other sharper documents. The key points contain the stress the commission wishes to convey. While not alarmist this key point, at least, is not enlightening. It quite easily coexists with the various 'nanorodic' interpretations.

\section{Population ageing and the future for living standards}

The crude inference from increasing dependency ratios and the falling aggregate labour force participation is that living standards of future generations will fall absolutely. A subtler version is that living standards will fall relatively. Both are wrong. The crude version means that future generations will be worse off in real terms than we are today. The subtler version has it that future generations will be worse off 'counterfactually'. That is, they will have lower real living standards than they would have had save for population ageing. The apparatus needed to refute the crude version is easy to assemble and to understand. I will set it out first and then perform some calculations. These will be sufficient also to refute the subtler 'relative' version of the 'our children and grandchildren ... will pay the price' thesis. 
Chart 4 Actual and projected 'dependency ratio' Australia 1950-2051

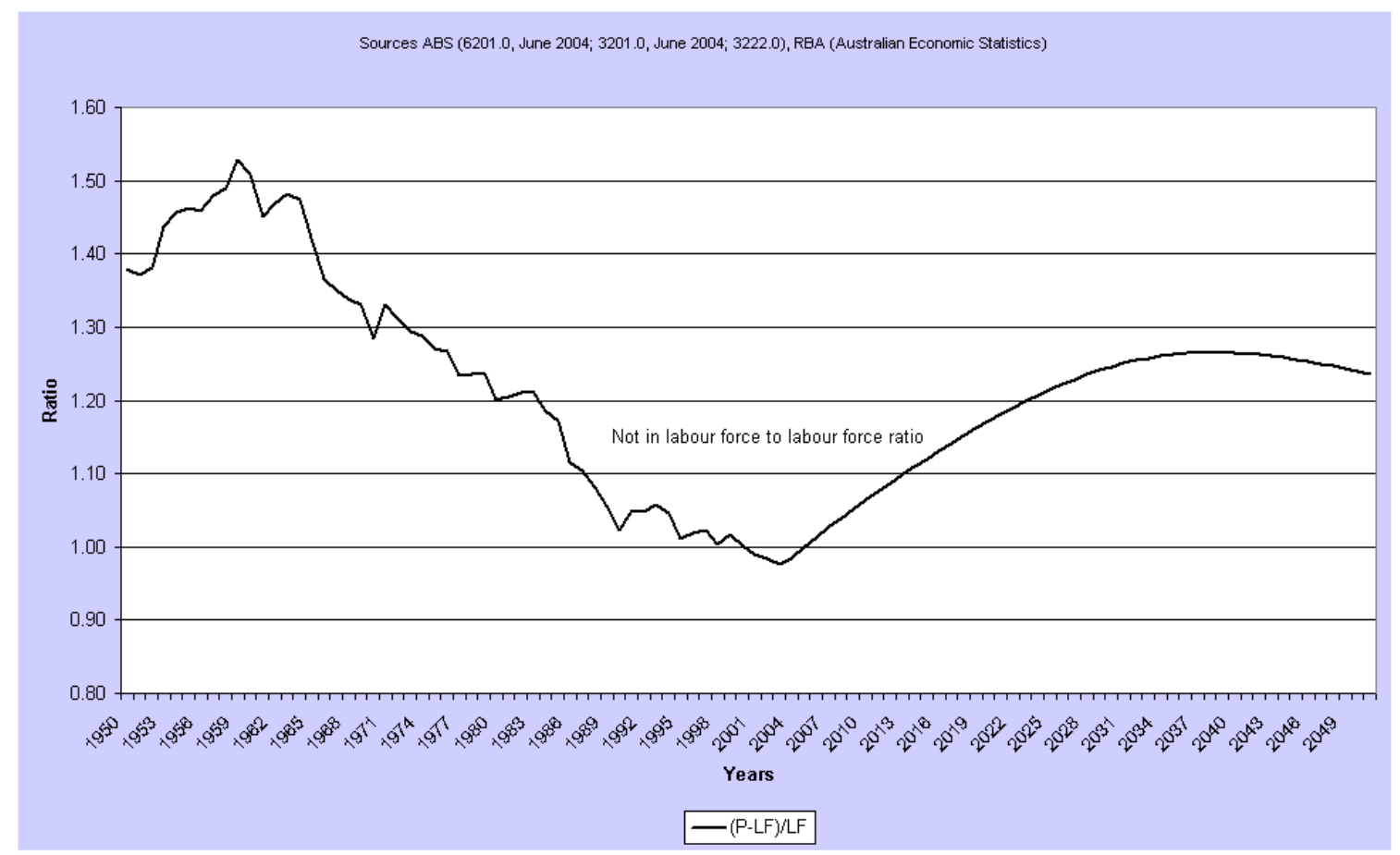

A workable proxy for living standards in this context is gross domestic product (GDP) per head of population $(\mathrm{P})$. Gross domestic product per capita is therefore the ratio (GDP/P). This ratio can be broken down further, or decomposed, as follows:

$$
(\mathrm{GDP} / \mathrm{P})=(\mathrm{GDP} / \mathrm{L}) /(\mathrm{P} / \mathrm{L})
$$

The ratio (GDP/L) is a proxy for labour productivity: in this case output per member of the labour force (L). The change in this ratio closely follows more usual labour productivity measures, namely output per employee or output per labour hour. It is sufficiently accurate for our purposes. Similarly the ratio $(\mathrm{P} / \mathrm{L})$ is a sufficiently accurate proxy for the dependency ratio used above, which in symbols is $[(\mathrm{P}-$ $\mathrm{L}) / \mathrm{L}]$, or the ratio of the numbers of those not in the labour force to those in the labour force.

Now a property of compound rates of growth or growth percentages in an equation like that above is that they are approximately additive when increases are relatively small. That is, the annual percentage growth rate in $(\mathrm{GDP} / \mathrm{L})$ less the annual percentage growth rate in $(\mathrm{P} / \mathrm{L})$ will equal the annual percentage growth rate in $(\mathrm{GDP} / \mathrm{P})$. In symbols this can be represented as follows:

$$
(\mathrm{GDP} / \mathrm{P})^{*} \approx(\mathrm{GDP} / \mathrm{L})^{*}-(\mathrm{P} / \mathrm{L})^{*}
$$

In words we can say that the annual percentage growth in living standards, or GDP per capita, will be approximately equal to the annual percentage increase in labour productivity less the annual percentage increase in the dependency ratio. Thus if productivity grows at 2 per cent per annum and the dependency ratio does likewise then living standards will not rise. Said in this way the apparatus is intuitively obvious. The PC adopts a reasonably similar approach in parts of its report (PC 2005, p. 52).

If we use more realistic projections, what will be the likely estimated effect on living standards of population ageing out to 2051? This is the year used in the ABS population projections. I claim no more than that the data in table 2 below are 'what if' results based on reasonable inputs. First I will use a labour productivity growth figure common to the 2003 Commonwealth budget Intergenerational Report and to the PC's 2005 report. This is an average annual labour productivity growth rate of 1.75 per cent. 
I will also assume, conservatively, that the cohort participation rates existing in 2003 will be the same in 2052. This is conservative for two reasons. Women's labour force participation will increase in all cohorts, with a possible exception of the 15-24 age group. This is because of increased educational participation. It is also reasonable to think that older workers will continue the trend to remain at work longer. Greater longevity and correspondingly better health will accentuate the trend. Nonetheless the conservative assumption delivers an average annual growth rate in the dependency ratio of 0.26 per cent.

Using the equation above these growth rates mean that GDP per capita will grow to 2051 at the rate of 1.49 per cent per year. GDP will grow at a modest rate of 2.1 per cent per annum. Living standards will, therefore, not only not fall, but they will grow in real terms. How much will living standards grow according to this conservative 'what if' scenario? Table 2 contains the dollar figures (in constant 2003 dollars). It shows that GDP per capita would more than double from 2003 to 2051.

I could offer other less conservative scenarios, but there would be little point. The data here are sufficient to refute fully the absolute version 'children and grand children will pay the price' thesis. More conservative scenarios would have to verge on the absurd to begin to dent the results, but they still would not alter the outcomes fundamentally. Our children and grandchildren have little to fear. They will live about twice as well in real dollar terms as we do. The PC says much the same in the body of its report (see e.g. 2005, p. xxvii), but it elides this conclusion in its key points summary, preferring again to stress that:

Assuming the average labour productivity performance of the past 30 years, per capita GDP growth will slump to 1.25 per cent per year by the mid 2020s, half its rate in 2003-04. (2005, p. xii)

Table 2 Conservative estimate of ageing impact Australia 2003-2051 with 2003 participation rates prevailing in 2051

\begin{tabular}{lccc}
\hline Description & Symbol & Actual to or at & ABS Series B \\
& & June 2003 & 2051 \\
Total GDP or income \$m & GDP & 738,812 & $1,995,334$ \\
Total labour force & $\mathrm{L}$ & $10,063,327$ & $11,818,742$ \\
Total population & $\mathrm{P}$ & $19,881,469$ & $26,421,541$ \\
'Productivity' \$ & GDP/L & 73,416 & 168,828 \\
Per capita GDP \$ & GDP/P & 37,161 & 75,519 \\
'Dependency' ratio (1) & (P-L)/L & 0.98 & 1.24 \\
'Dependency' ratio (2) & P/L & 1.98 & 2.24
\end{tabular}

Sources ABS (6201.0, June 2004; 3201.0, June 2004), RBA (Australian economic statistics). All 2003 constant (chain value) dollars. Series B, mid-range population projections (ABS 2003, 3222.0).

The commission also neglects to note in its selective key points summary that, by its own reckoning, per capita GDP growth will be greater than 1.6 per cent per annum by the 2040s. Would this be to boom rather than to slump? Use of pejoratives can be telling. Again it is a case of more heat than light.

What can we make of the hypothetical argument that future generations will be relatively worse off? Does this argument have traction? It is a curious way of posing the argument, and it does not have traction in reality. Relative to living standards today, and in each of the years up to 2051, each successive 'generation' should be better off in real terms. That is what average annual growth in GDP per capita means, provided it is maintained year on year. Whether the figure is an average of 1.5 per cent, 1.25 per cent or whatever, the next year's population will be better off, if only in real dollar terms. They might become sadder, less enlightened and spiritually deflated, but they will, on average, have more in their pockets. In fact they will have double the real incomes in 2051 that we have now. 
The only senses in which future generations might be relatively worse off would be to compare them with their successors or against an external standard. The PC's report does in fact use a counterfactual standard in which the Australian population does not age (2005, p. xvii). It compares estimated actual GDP per capita growth against rates that might prevail were the population not to age. Comparing counterfactuals can be a useful exercise. For example, we might compare the relative impacts of government investments in infrastructure against corresponding tax cuts. However, it is not as if we can choose not to have an ageing population. Therefore the PC's exercise is not really very meaningful. Moreover, while the PC does not use words like 'relatively worse off', its comparison tends to be pejorative precisely in this sense. (See the section titled 'Future economic growth - An age of diminished expectations?' in the report overview and chapter 5.)

This section of the paper has answered the second set of claims presented in the dominant ageing literature. The model used here has allowed us to see, using relatively straightforward arguments and reasonable projections, that:

\section{An increased dependency ratio will not 'reduce' average living standards in the future. In fact:}

c. Average living standards will rise absolutely, on conservative assumptions by about double their real 2003 dollar amounts.

d. Moreover, the argument that average living standards will fall relatively is meaningless because: (a) the population will age regardless and (b) absolute living standards will about double in 2003 real dollar terms regardless.

In the next section I will discuss what I believe is the true motive behind the dominant positions on ageing and the economy. This is that an ageing population will increase the need for government spending. Those of neo-liberal or economic rationalist bent find this prospect anathema.

\section{The effect of ageing on government spending and living standards}

We saw in the introduction that the role of government is never far from the centre of economic policy discussions. As Philip York put it: 'Governments around the world are in crisis as pension and healthcare costs are increasing exponentially and, if governments are in crisis, citizens are in crisis.' (2004, p. 33). York happens to represent QBL Funds management, and his remedy (apart from making death less 'optional') is that:

The government needs us to become more self sufficient, more self funding. The pension system has to be seen mainly as a poverty prevention mechanism, as opposed to an income replacement. Personally funded superannuation needs to be seen as the main pillar of aged income support. (2004, p. 33)

The message of the PC and others of a similarly more serious ilk is again subtler. Yet their argument is essentially the same. Unless various policy measures are implemented soon the cost of an ageing population will be born inter-generationally by future taxpayers. They will experience higher taxes and or inferior government services. This is what the PC says in its key points summary:

- While taxation revenue will largely track GDP growth, government expenditure is likely to rise more rapidly, placing budgets under considerable pressure.

- Although education and some welfare payments are projected to increase more slowly than GDP, government spending on health, aged care and pensions will grow at a faster rate.

- The major source of budgetary pressure is health care costs, which are projected to rise by about 4.5 percentage points of GDP by 2044-45, with ageing accounting for nearly one-half of this. 
- In the absence of policy responses, the aggregate fiscal gap will be around 6.4 percentage points of GDP by $2044-45$, with an accumulated value over the forty years of around $\$ 2200$ billion in 2002-03 prices.

- On past trends, much of this could be expected to be borne by the Australian Government, but there are significant potential burdens faced by State and Territory Governments.

- A range of policy measures will be needed to reduce the fiscal pressure from ageing and/or to finance the fiscal gap. (2005, p. xvii; original formatting)

This summary is greatly exaggerated and selective. It lacks perspective and comes from an implicit understanding that an increase in of the role of government in the economy is bad per se. Why else would the PC focus on a 40-year accumulated figure (\$2200 billion) if not to shock? Fortunately it is relatively easy to clarify the issues with the help of a simple growth model.

How large is the supposed fiscal 'burden'? Per capita GDP, as a proxy for living standards, is a reasonable variable to start with. The aim of the model is to show how general government taxation and spending redistributes average GDP per person (GDP/P) as the ratio of general government spending to population $(\mathrm{G} / \mathrm{P})$ rises or falls. This ratio will, other things being equal, rise or fall with the dependency ratio. The model is:

$$
(\mathrm{G} / \mathrm{GDP})^{*} \approx(\mathrm{G} / \mathrm{P})^{*}-(\mathrm{GDP} / \mathrm{P})^{*}
$$

That is, the annual compound percentage growth in the proportion of general government spending to GDP (G/GDP)* will approximately equal the annual compound percentage growth in the ratio of government spending to the population less that in per capita GDP. We can also insert the terms of the model used in the previous section into this equation:

$$
(\mathrm{G} / \mathrm{GDP})^{*} \approx(\mathrm{G} / \mathrm{P})^{*}-(\mathrm{GDP} / \mathrm{L})^{*}+(\mathrm{P} / \mathrm{L})^{*}
$$

In other words government spending as a proportion of GDP will rise with increases in the rates of growth of government spending per person and the dependency ratio and fall with the rate of growth of labour productivity. If we imagine conservatively that the ratio of government spending to GDP rises at the rate of 2 per cent per annum - a rate higher than the rate of growth of the proportion of the population older than 65 - we can use the earlier data to estimate what might happen to living standards. That is, we can use the annual 1.75 per cent productivity and 0.26 per cent dependency ratio growth figures. Table 3 presents the 2003 real dollar figures.

The data in table 3 give us the rise in the proportion of government spending and taxation of about 6.0 per cent to 2051 that the PC estimates. However, two points need to be made. The first is that the assumptions are very conservative. GDP would grow only by 2.1 per cent per annum on this scenario. By way of comparison, it has averaged about 3.5 per cent per annum over the past 40 years. The second is one that is conveniently ignored, namely that after tax PAYG tax payers still receive more than doubled incomes even if they pay all the tax required to meet the 'fiscal burden', 'fiscal challenge' or whatever other name the proponents of nanorodic ageing crisis thinking want to give it.

To be blunt, the whole thing is a furphy. Economics should be about living standards not ratios. If the ratio of government spending rises because our population ages, so what? Isn't it good that our economy can adapt in this way to human needs? Isn't this better than having human needs adapt to a preconceived ratio? It is perhaps a cheap shot but, if we begin to think in the manner of a Philip York, we end up talking about the optionality or not of death! In short:

The 'cost' of an ageing population can be readily accommodated inter-generationally by taxpayers:

- Our children and grandchildren will experience higher taxes, but their real take-home incomes will still more than double. Only someone obsessed with the neo-liberal mantra of small government (or someone fixated on ratios) would think this a 'burden'. 
Table 3 Estimate of 'fiscal challenge' in Australia 2003-2051 with 2003 participation rates in 2051

\begin{tabular}{|c|c|c|}
\hline Description & $\begin{array}{c}\text { Actual to or } \\
\text { at } \\
\text { June } 2003\end{array}$ & $\begin{array}{c}A B S \\
\text { Series } B \\
2051\end{array}$ \\
\hline Growth in per capita government spending per annum $(G / P)^{*}$ & \multicolumn{2}{|c|}{$2.0 \%$} \\
\hline Less Growth in per capita GDP per annum $(G D P / P)^{*}$ & \multicolumn{2}{|c|}{$1.5 \%$} \\
\hline Growth in General government spending to $G D P(G / G D P) *$ per annum & \multicolumn{2}{|c|}{$0.5 \%$} \\
\hline Per capita $G D P(G D P / P) \$$ & 37,161 & 75,519 \\
\hline Per capita government spending $(G / P) \$$ & 7,734 & 20,008 \\
\hline General government spending to $G D P(G / G D P) \%$ & 20.8 & 26.5 \\
\hline Average annual labour earnings $(W / L) \$$ & 37,869 & 87,084 \\
\hline Government spending to labour $(G / L) \$$ & 15,279 & 44,729 \\
\hline Change in $G / L$ due to change in $G / P$ ratio $\$$ & n.a. & 5634 \\
\hline $\begin{array}{l}W / L \text { with change in } G / L \text { fully allocated to } P A Y G \text { (i.e. pre-tax } W / L \\
\text { less tax increase due to ageing) }\end{array}$ & 37,869 & 81,884 \\
\hline
\end{tabular}

\section{Conclusion}

The data and relatively simple arguments in this paper have established the conclusions below. The dominant view on the subject, namely that ageing will create economic problems if not a crisis, is plainly false. If our approach is not selective and its perspective is broad such conclusions as the following are inescapable:

1. While population ageing has and will reduce aggregate labour force participation rates:

1.1. Early retirement has not cut labour force participation among older workers. Rather older cohort participation rates have been increasing because of increased female participation. This trend should continue.

1.2. Lower aggregate labour force participation rates and the dependency ratio are very similar ratios and change over time for much the same reasons. The data by themselves do not demonstrate that the dependency ratio's projected rise is significant.

2. An increased dependency ratio will not 'reduce' average living standards in the future. In fact:

a. Average living standards will rise absolutely, on conservative assumptions by about double their real 2003 dollar amounts.

b. Moreover, the argument that average living standards will fall relatively is meaningless because: (a) the population will age regardless and (b) absolute living standards will about double in 2003 real dollar terms regardless.

3. The 'cost' of an ageing population can be readily accommodated intergenerationally by taxpayers:

c. Our children and grandchildren will experience higher taxes, but their real takehome incomes will still more than double. Only someone obsessed with the neoliberal mantra of small government (or someone fixated on ratios) would think this a 'burden'.

The background arguments in this paper will help us to discuss more important problems, such as skills shortages and skills formation in Australia, with greater clarity. They will do so by explaining that population ageing is not such an economic problem after all. Attention should be diverted to skills, education and making older workers and retirees feel valued, in part for their skills. As a society we must mot make older workers and retirees feel like they are a burden. They are our parents and 
grandparents. They are we. A flourishing life, at whatever age, is their due. It is our due, just as it is our children's and grandchildren's.

\section{References}

ABS [Australian Bureau of Statistics] 2006, Year book Australia, Cat. No. 1310.0, Canberra. 2006b, Labour force Australia, Cat. No. 6201 .0, Canberra.

_ 2005a, Australian demographic statistics, Cat. No. 3101.0, Canberra. 2005b, Population Projections, Australia, 2004 to 2101, Cat. No. 3222.0, Canberra. 2004, Australian historical population statistics, Cat. No. 3105.0.65.001, Canberra.

Ball, P 2005, 'Nanorods produce more heat than light', Nanozone news, Nature Publishing Group, 23 June 2005.

Chou C-H, Chen C-D \& Wang CRC 2005, 'Highly efficient, wavelength-tunable, gold nanoparticle based optothermal nanoconvertors' The journal of physical chemistry B, vol. 109/22, pp. 1113511138.

Howard, J 2002, 7.30 report, ABC TV, Australian Broadcasting Commission, Sydney, 27 November 2002.

Nietzsche, F 1885, Beyond good and evil, from Nietzsche's complete works, trans. Helen Zimmern, 1974, Gordon Press, New York.

OECD [Organisation of Economic Co-operation and Development] 2004, 'Ageing societies and the looming pension crisis', Paris, [online]http://www.oecd.org/document/59/0,2340,en 264920118525126991111 1,00.html, consulted 31 December 2005.

Productivity Commission 2005, The economic implications of an ageing Australia, research report, Canberra.

RBA [Reserve Bank of Australia] 2004, Australian economic statistics, 1949-1950 to 1996-1997, Occasional paper No. 8. Sydney, [online] http://www.rba.gov.au/Statistics/op8 index.html, consulted 11 December 2004.

York, P 2004, 'The retirement crunch: Older, poorer and unsustainable', New observer, May 2004, Melbourne, pp. 32-33 
